ETNIK : Jurnal Ekonomi - Teknik

ISSN: 2808-6694 (Online);2808-7291 (Print)

Jurnal Homepage https://etnik.rifainstitute.com

\title{
Strategi Pemanfaatan Gofood untuk Ekspansi UMKM Selama Pandemi Covid-19 di Banyu Urip Kidul, Surabaya
}

\author{
Djoko Adi Prasetyo, Irfananda Devalia Nifatul Imamah, \\ Gilang Adi Firmansyah
}

Universitas Airlangga

\section{Informasi Artikel}

Histori Artikel:

Diterima 09 January 2022

Direvisi 13 January $\mathbf{2 0 2 2}$

Diterbitkan 20 January 2022

Email Author:

firmansyahgilangadi@gmail.com

\begin{abstract}
The world is facing the Coronavirus Disease of 2019 (Covid-19) pandemic which has major implications for all sectors, namely education, economy, health and socio-politics. The government's effort to suppress the surge in Covid-19 infections and death rates in Indonesia is by implementing the Level 4 and 3 Community Activity Restrictions (PPKM) for the Java and Bali regions. These restrictions make it difficult for Indonesia to realize the 8th Sustainable Development Goals (SDG), namely decent work and economic growth, especially for the people of Banyu Urip Kidul. This is because these restrictions have an impact on Micro, Small and Medium Enterprises (MSMEs) in the food sector in Banyu Urip Kidul who do not use online media, one of which is GoFood. The method used in this community service is carried out based on the analysis of the results of observations and discussions with community members who live in Banyu Urip Kidul, Surabaya, East Java. Thus, the activity in the form of counseling about the use of GoFood media as a strategy for managing MSMEs during the pandemic was carried out with the aim that residents could expand their culinary businesses through GoFood. Meanwhile, this knowledge is new for residents so that residents are enthusiastic when participating in the counseling as evidenced by the various questions asked.
\end{abstract}

Keyword- Strategy, Expansion, MSME, Covid-19

\begin{abstract}
ABSTRAK
Dunia sedang menghadapi pandemi Coronavirus Disease of 2019 (Covid-19) yang memberikan implikasi besar pada seluruh sektor yaitu pendidikan, ekonomi, kesehatan dan sosial politik. Upaya pemerintah untuk menekan lonjakan infeksi Covid-19 dan tingkat kematian di Indonesia yaitu dengan menerapkan Pemberlakuan Pembatasan Kegiatan Masyarakat (PPKM) Level 4 dan 3 untuk wilayah Jawa dan Bali. Pembatasan tersebut mempersulit Indonesia dalam mewujudkan Sustainable Development Goals (SDG) tujuan
\end{abstract}


ke-8 yaitu pekerjaan layak dan pertumbuhan ekonomi terutama pada warga Banyu Urip Kidul. Hal tersebut dikarenakan pembatasan tersebut berdampak pada pelaku Usaha Mikro, Kecil dan Menengah (UMKM) pada sektor makanan di Banyu Urip Kidul yang tidak memanfaatkan media online, salah satunya GoFood. Metode yang digunakan dalam pengabdian masyarakat ini dilaksanakan berdasarkan analisis hasil observasi dan diskusi dengan warga masyarakat yang bertempat tinggal di Banyu Urip Kidul, Surabaya, Jawa Timur. Dengan demikian, kegiatan berupa penyuluhan tentang pemanfaatan media GoFood sebagai strategi pengelolaan UMKM di masa pandemi dilakukan dengan tujuan warga dapat melakukan ekspansi pada usaha kuliner yang dimiliki melalui GoFood. Adapun, pengetahuan tersebut merupakan hal baru bagi warga sehingga warga antusias saat mengikuti penyuluhan dibuktikan dengan berbagai pertanyaan yang diajukan.

Kata Kunci - Strategi, Ekspansi, UMKM, Covid-19

\section{PENDAHULUAN}

Dunia sedang menghadapi pandemi Coronavirus Disease of 2019 (Covid-19) yang memberikan implikasi besar pada seluruh sektor yaitu pendidikan, ekonomi, kesehatan dan sosial politik. Terhitung sejak Maret 2020 lalu, pandemi Covid-19 resmi melanda Indonesia selama 16 bulan dengan jumlah kematian sebesar 107.096 jiwa per 8 Agustus 2021 (Satuan Tugas Penanganan Covid-19, 2021). Adanya varian baru dari virus ini yang disebut dengan Delta membuat Indonesia berada di posisi ke 2 di Asia (World Health Organization, 2021) dengan jumlah kasus positif sebesar 3.666.031 per 8 Agustus 2021 (Satuan Tugas Penanganan Covid-19, 2021).

Upaya pemerintah untuk menekan lonjakan infeksi Covid-19 dan tingkat kematian di Indonesia yaitu dengan menerapkan Pemberlakuan Pembatasan Kegiatan Masyarakat (PPKM) Darurat yang berlaku pada 3 - 20 Juli lalu. Pembatasan ini dilakukan karena lonjakan infeksi tersebut tidak diiringi dengan fasilitas kesehatan yang memadai sehingga banyak rumah sakit yang melampaui kapasitas (Paramaditha, 2021). Pemerintah kemudian menerapkan PPKM Level 4 dan 3 sejak 21 Juli menggantikan PPKM Darurat yang kemudian diperpanjang hingga 16 Agustus 2021 untuk wilayah Jawa dan Bali (Murti, 2021).

Salah satu aturan dari pembatasan ini adalah kegiatan di pusat perbelanjaan, mal ataupun pusat perdagangan ditutup sementara. Selain itu, pasar tradisional, toko kelontong dan pasar swalayan hanya diperbolehkan menerima pengunjung maksimal 50\% dari kapasitas dan beroperasi sampai pukul 20.00 saja (Komite Penanganan Covid-19 dan Pemulihan Ekonomi Nasional, 2021). Tidak heran, banyak ekonom memprediksi bahwa pertumbuhan ekonomi Indonesia akan anjlok di kuartal III-2021 ini (Handayani and Kurniawan, 2021; Thomas, 2021; Ulya and Sukmana, 2021). Hal ini tentunya akan mempersulit Indonesia dalam mewujudkan Sustainable Development Goals (SDGs) ke-8 (Kementerian Perencanaan Pembangunan Nasional, 2020).

SDGs ke-8 bertujuan untuk meningkatkan pertumbuhan ekonomi yang inklusif dan berkelanjutan, kesempatan kerja yang produktif dan menyeluruh, serta pekerjaan yang layak untuk semua (Kementerian Perencanaan Pembangunan Nasional, 2020). Namun, pembatasan yang 
terjadi justru akan membuat pertumbuhan ekonomi menurun dan banyak masyarakat yang harus kehilangan pekerjaan. Sejak pandemi berlansung, Indonesia telah memasuki resesi dengan menyusutnya pertumbuhan ekonomi sebesar 3.49 persen pada 2020 lalu (Akhlas, 2020). Tidak hanya itu, 3.5 juta pekerja terkena Pemutusan Hubungan Kerja (PHK) (Karunia dan Setiawan, 2020).

Pembatasan tersebut juga sangat berdampak pada pelaku Usaha Mikro, Kecil dan Menengah (UMKM). Mobilisasi yang dibatasi menyebabkan masyarakat harus meminimalisir keluar rumah sehingga para pelaku UMKM kesulitan menjalankan usahanya. Namun, di tengah PPKM ini layanan pesan antar berbagai kebutuhan seperti makanan, minuman, dan kebutuhan pokok lainnya justru menjadi solusi. Saat ini, layanan pesan antar online sangat populer di Indonesia terutama saat pandemi berlangsung. Pasalnya, masyarakat tidak perlu keluar rumah untuk memenuhi kebutuhan. Salah satu layanan pesan antar online yang populer adalah GoFood.

GoFood merupakan layanan pesan antar online di aplikasi Gojek yang memungkinkan pengguna membeli makanan dan minuman dari rumah (GoBiz, 2020). Tentunya layanan ini akan tetap berjalan meskipun mobilisasi saat pandemi dibatasi, terbukti dengan meningkatnya pendapatan GoFood sebesar 20 kali lipat dalam empat tahun terakhir (Sasongko, 2021). Hal tersebut didukung dengan hasil survei oleh Lembaga Demografi Fakultas Ekonomi dan Bisnis (FEB) Universitas Indonesia (UI) yang menyatakan bahwa 92\% responden memesan makanan melalui GoFood selama pandemi berlangsung (Jayani dan Ridhoi, 2020). Fakta tersebut menjadi angin segar bagi UMKM yang terdampak pandemi karena dapat memanfaatkan media ini untuk memperluas ekspansi usaha makanannya. Apalagi saat ini GoFood telah memiliki 750 ribu mitra usaha kuliner (Setyowati, 2021).

Banyu Urip Kidul adalah wilayah yang terletak di Surabaya dengan jumlah penduduk sebanyak 227 orang. Sebagian besar warga di wilayah ini bermata pencaharian sebagai buruh pabrik, pegawai swasta dan pedagang. Tentunya, wilayah ini terkena dampak PPKM level 4 karena Surabaya merupakan salah satu penyumbang kasus positif Covid-19 dan angka kematian tertinggi di Indonesia (CNN Indonesia 2020). Selain itu, warga di wilayah ini juga termasuk ke dalam 3.5 juta pekerja yang terkena Pemutusan Hubungan Kerja (PHK) (Karunia dan Setiawan, 2020). Akibatnya, warga puh beralih profesi menjadi pedagang makanan dan minuman. Namun, kendala lain yang muncul adalah pedagang tersebut tidak melek teknologi dan adanya PPKM membuat usahanya terhambat. Oleh karena itu, inovas diperlukan untuk memperkenalkan warga kepada teknologi, khususnya GoFood. Selain itu, pembinaan juga dilakukan untuk mendampingi dan memastikan warga dapat menggunakan GoFood dengan baik dan benar guna memperluas ekspansi usahanya.

\section{METODE}

Pengabdian masyarakat ini dilaksanakan berdasarkan analisis hasil observasi dan diskusi dengan warga masyarakat yang bertempat tinggal di Banyu Urip Kidul, Surabaya, Jawa Timur. Permasalahan yang sedang terjadi adalah tidak ada peningkatan strategi pengelolaan UMKM yang bergerak pada sektor makanan milik warga Banyu Urip Kidul di era pandemi Covid-19. Oleh karena itu, solusi yang ditawarkan melalui program pengabdian masyarakat yang diadakan oleh Lembaga Pengabdian dan Pengembangan Masyarakat (LPPM) dan mahasiswa Universitas Airlangga ini adalah penyuluhan tentang pemanfaatan GoFood sebagai strategi pengembangan UMKM di masa pandemi. 
Kegiatan tersebut dilaksanakan pada tanggal 8 Agustus 2021 di Banyu Urip Kidul. Pelaksanaan kegiatan tersebut tentunya memiliki beberapa hambatan, yaitu kondisi pandemi dan pemberlakukan PPKM di kota Surabaya. Oleh karena itu, penyesuaian yang diambil adalah melaksanakan kegiatan secara online melalui Zoom Meeting setelah melakukan diskusi antar anggota dan merupakan permintaan dari perwakilan warga Banyu Urip Kidul.

Kegiatan tersebut dilaksanakan dalam beberapa tahap yaitu persiapan, pelaksanaan dan evaluasi. Pada tahap persiapan meliputi pembentukan panitia pelaksana kegiatan penyuluhan, pembuatan proposal, survei lokasi pelaksanaan kegiatan penyuluhan, melakukan proses perizinan ke lokasi kegiatan, membuat grup WhatsApp untuk pemberitahuan kegiatan penyuluhan kepada masyarakat setempat.

Kegiatan dilaksanakan dari pukul 09.00 - 11.00 WIB, dengan susunan acara yaitu pembukaan, pemutaran video mengenai aplikasi Gojek sebelum acara penyuluhan berlangsung, penyampaian materi tentang GoFood dan GoBiz, tanya jawab dengan pemateri setelah penyuluhan, dan penutupan. Materi yang disampaikan meliputi fitur-fitur yang tersedia pada GoBiz, tutorial pendaftaran, tutorial aktivasi, cara bertrantaksi dengan kode Quick Response (QR) dan kiat-kiat UMKM selama pandemi. Materi tersebut disampaikan dengan presentasi dan pemutaran video tutorial. Selanjutnya, observasi dilakukan secara langsung saat penyuluhan dan pemutaran video tutorial dengan melihat interaksi antara peserta dengan pemateri dan keaktifan peserta melalui sesi tanya jawab.

Adapun tahap evaluasi yaitu pembuatan laporan hasil kegiatan penyuluhan dan penyerahan laporan ke LPPM Universitas Airlangga. Evaluasi dilakukan untuk mengetahui respon peserta terhadap pelaksanaan kegiatan ini dan dilakukan terhadap tingkat pemahaman dan partisipasi peserta.

\section{HASIL DAN PEMBAHASAN}

Kegiatan tersebut dilakukan untuk meningkatkan kesadaran warga bagaimana usaha kuliner melalui GoFood dapat menjadi strategi bagi pelaku UMKM pada sektor makanan di masa pandemi. Kegiatan tersebut telah berjalan dengan baik dan lancar. Pelaksanaan kegiatan tersebut dilakukan oleh tim pelaksana pengabdian masyarakat yang terdiri dari 9 mahasiswa dan 1 dosen serta dibantu oleh warga setempat. Adapun kegiatan yang dilakukan berupa penyuluhan untuk pelaku UMKM pada sektor makanan tentang pemanfaatan GoFood sebagai strategi pengembangan UMKM di masa pandemi.

Kegiatan penyuluhan dilakukan menggunakan metode diskusi secara daring dengan menggunakan Zoom Meeting. Narasumber pada kegiatan tersebut merupakan seorang mahasiswi yang telah berpengalaman menggunakan media GoFood di bidang usaha kuliner. Sedangkan peserta kegiatan adalah ibu-ibu di Banyu Urip Kidul dengan jumlah peserta sebanyak 25 orang. Kegiatan tersebut bertujuan untuk memberikan pengetahuan baru kepada pelaku UMKM pada sektor makanan di Banyu Urip Kidul tentang pemanfaatan GoFood dalam melakukan ekspansi.

Materi pada kegiatan tersebut dapat tersampaikan dengan jelas karena waktu yang disediakan sangat memadai. Materi yang disampaikan berupa penjelasan singkat tentang GoFood dan GoBiz, tutorial pendaftaran atau pembuatan akun, tutorial aktivasi, penjelasan fitur-fitur yang tersedia, cara transaksi menggunakan kode QR dan kiat-kiat UMKM menghadapi pandemi, serta sesi tanya 
jawab. Hasil observasi saat kegiatan berlangsung adalah para warga khususnya pelaku UMKM memang belum memiliki pengetahuan dasar tentang penggunaan GoFood dan layanan pesan-antar online lainnya sehingga mereka antusias dalam mengikuti kegiatan ini.

Kegiatan tersebut berjalan sesuai rencana meskipun terdapat beberapa penyesuaian waktu dengan kondisi dan situasi lingkungan masyarakat setempat akibat pemberlakuan PPKM di Surabaya. Kegiatan tersebut dimulai pada pukul 09.00 WIB yang juga dihadiri oleh Ibu Ketua Pembinaan Kesejahteraan Keluarga (PKK) dan Ibu Rukun Tetangga (RT) setempat.

Selanjutnya, kegiatan berlangsung dengan penyampaian materi oleh Fellycita Kartika, mahasiswi Institut Teknologi Sepuluh Nopember yang memiliki usaha kuliner ayam goreng dengan nama Kukukriyuuksby. Gambar 2 berikut ini merupakan penjelasan awal mengenai fitur-fitur yang tersedia pada aplikasi GoBiz antara lain fitur rekapitulasi transaksi, beragam fitur pembayaran non tunai, serta pengaturan jam operasional restoran. Selanjutnya, ditampilkan video tentang tutorial pendaftaran atau pembuatan akun sebagai langkah awal dalam membuka usaha kuliner di GoFood seperti yang tertera pada Gambar 3. Adapun, video tersebut telah dikirimkan kepada warga untuk memudahkan warga ketika ingin menonton kembali.

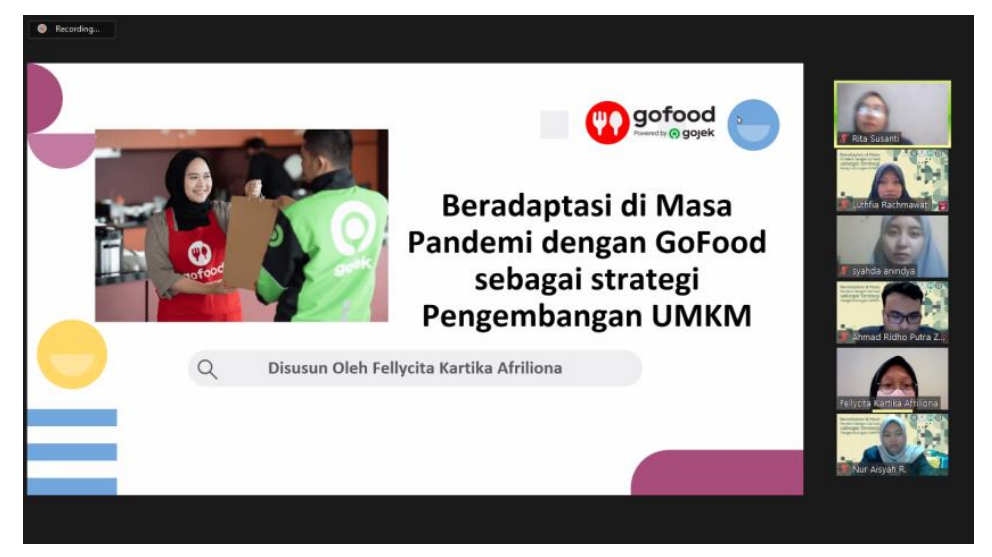

Gambar 1. Penyampaian Materi Penyuluhan

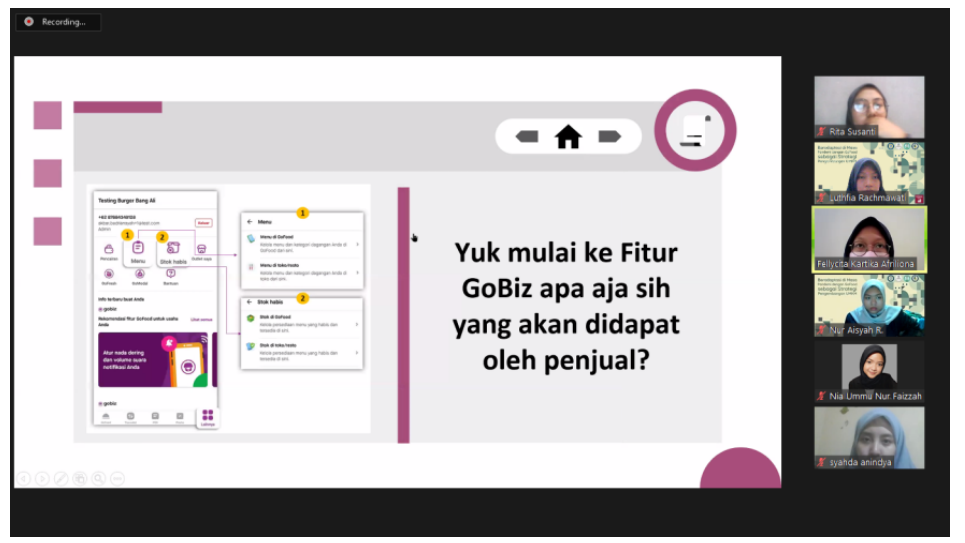

Gambar 2. Penjelasan Tentang GoBiz 


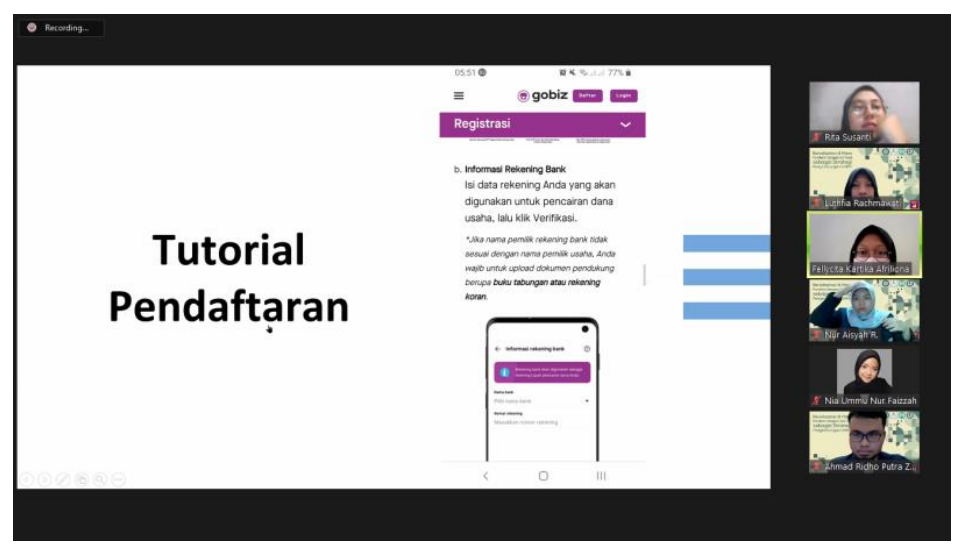

Gambar 3. Tutorial Pendaftaran Aplikasi GoBiz

Gambar 4 berikut ini merupakan penjelasan tentang fitur promo yang tersedia pada layanan GoFood untuk memudahkan pelaku usaha dalam meningkatkan transaksi penjualan. Fitur promo yang tersedia antara lain promo menu, promo total belanja, dan promo ongkir. Selain itu, pemateri juga memberikan tips berjualan pada masa pandemi seperti yang tertera pada Gambar 5 berikut ini. Hal ini dikarenakan perlu strategi baru yang sesuai dengan kebutuhan pasar dan keadaan perekonomian masyarakat akibat adanya pandemi. Seperti yang diketahui bahwa terdapat banyak rintangan dan kesulitan yang harus dilalui oleh para pelaku UMKM pada masa pandemi ini namun hal tersebut dapat dilalui dan akan menjadi pelajaran baru. Selanjutnya, Gambar 6 merupakan sesi tanya jawab yang dilaksanakan setelah materi selesai. Sesi tersebut diharapkan mampu menambah pengetahuan serta wawasan baru bagi warga Banyu Urip Kidul. Materi yang disampaikan tersebut dapat meningkatkan pengetahuan warga Banyu Urip Kidul yang dibuktikan dengan respon aktif dari warga melalui pertanyaan-pertanyaan yang diajukan. Selain itu, masyarakat juga memperhatikan demonstrasi yang dilakukan melalui media video tersebut.

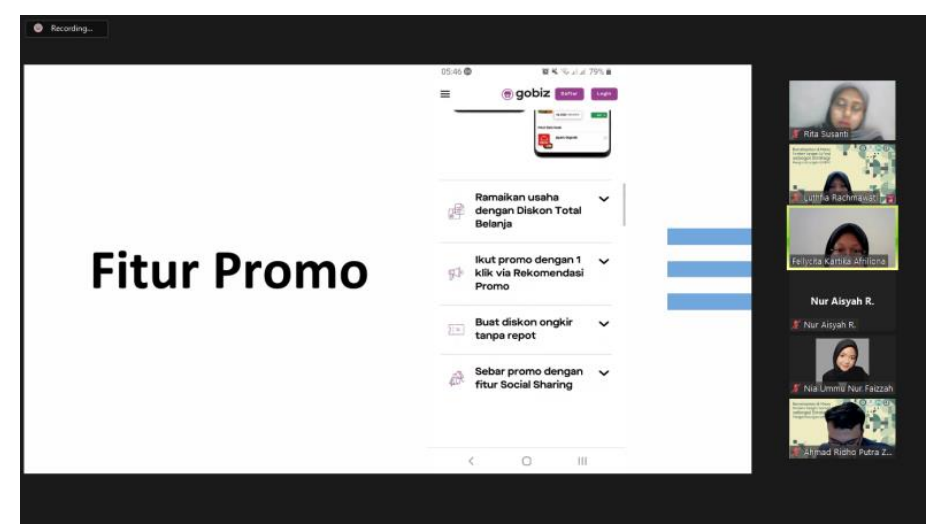

Gambar 4. Penjelasan fitur Promo Pada GoFood

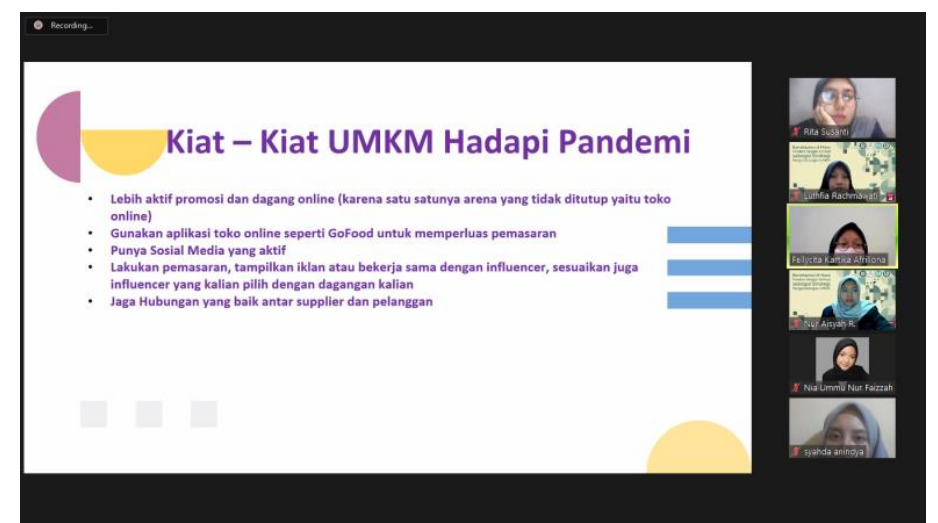

Strategi Pemanfaatan Gofood untuk Ekspansi UMKM Selama Pandemi Covid-19 di Banyu Urip Kidul, Surabaya 


\section{Gambar 5. Kiat-Kiat UMKM Menghadapi Pandemi}

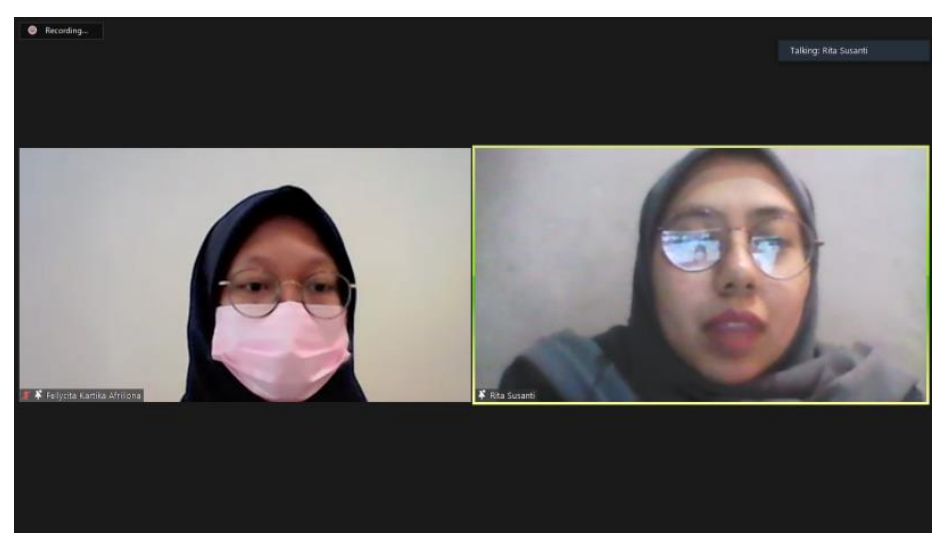

\section{Gambar 6. Sesi Tanya Jawab}

Kegiatan tersebut menghasilkan beberapa informasi baru bagi para pelaku UMKM pada sektor makanan, yaitu penggunaan media online yang terbukti efektif dalam meningkatkan omzet dan menghemat biaya operasional. Selain itu, kesempatan untuk melakukan ekspansi usaha lebih besar dengan luasnya jaring pemasaran dan promosi yang dilakukan oleh media online tersebut. Sedangkan bagi pembeli, media online seperti GoFood memberikan kemudahan dalam bertransaksi karena tidak dibatasi oleh ruang dan jarak. Namun, kendati demikian pelakasanan kegiatan ini memiliki beberapa hambatan berupa akses internet yang kurang memadai bagi warga serta kesadaran masyarakat akan pentingnya pemanfaatan media online untuk usaha kuliner di masa pandemi yang belum menyeluruh.

\section{SIMPULAN}

Pengabdian kepada masyarakat ini memberikan pengetahuan pada pelaku UMKM yang bergerak di sektor makanan dengan cara mengadakan penyuluhan di Banyu Urip Kidul, Surabaya. Penyuluhan tersebut membahas tentang pemanfaatan GoFood sebagai strategi pengembangan UMKM di masa pandemi. Kegiatan tersebut memberikan wawasan baru bagi warga sehingga warga antusias mengikuti kegiatan dibuktikan dengan pertanyaan-pertanyaan yang diajukan.

Kegiatan pengabdian masyarakat ini perlu adanya keberlanjutan agar para pelaku UMKM pada sektor makanan di Banyu Urip Kidul dapat melakukan ekspansi pada usaha kulinernya sehingga dapat memperbaiki tingkat perekonomian.

Penulis mengucapkan terima kasih atas bantuan pendanaan dari Keputusan Rektor Universitas Airlangga mengenai Pelaksanaan Program Pengabdian Masyarakat Universitas Airlangga Tahun 2021 sesuai dengan Surat Perjanjian Penugasan Pelaksanaan Pengabdian Kepada Masyarakat Universitas Airlangga Tahun Anggaran 2021. Penulis mengucapkan terima kasih juga atas bantuan dari tim pengabdian masyarakat yang bertugas serta para perangkat desa di Banyu Urip Kidul, Surabaya.

\section{BIBLIOGRAFI}

CNN Indonesia. (26 Agustus 2020). "Surabaya Sumbang Kasus Positif Dan Kematian Corona Tertinggi.” https://www.cnnindonesia.com/nasional/20200826130647-20-539476/surabayasumbang-kasus-positif-dan-kematian-corona-tertinggi. (10 Agustus 2021)

GoBiz. (30 September 2020). Apa itu Fitur GoFood? Gobiz. Retrieved from 
https://bantuan.gobiz.co.id/s/article/Apa-itu-fitur-GoFood (10 Agustus 2021).

Handayani, M. and Kurniawan, D. (23 Juli 2021). Emergency PPKM Make Indonesia's Economic Growth in Quarter III 2021 Far from Sri Mulyani and BI's Expectations? Voi. Retrieved from https://voi.id/en/economy/69708/emergency-ppkm-make-indonesias-economicgrowth-in-quarter-iii-2021-far-from-sri-mulyani-and-bis-expectations (10 Agustus 2021).

Jayani, D. H. and Ridhoi, M. A. (12 Oktober 2020). Mayoritas Konsumen GoFood Memesan Makanan Untuk Diri Sendiri. Katadata. Retrieved from https://databoks.katadata.co.id/datapublish/2020/10/12/mayoritas-konsumen-gofoodmemesan-makanan-untuk-diri-sendiri (10 Agustus 2021).

Karunia, A. M. dan Setiawan, S. R. D. (4 Agustus 2020). Imbas Corona, Lebih dari 3.5 Juta Pekerja Kena PHK dan Dirumahkan. Kompas.com. Retrieved from https://money.kompas.com/read/2020/08/04/163900726/imbas-corona-lebih-dari-3-5juta-pekerja-kena-phk-dan-dirumahkan?page =all (10 Agustus 2021).

Kementerian Perencanaan Pembangunan Nasional. (2020). Tujuan Pembangunan Berkelanjutan. Retrieved from http://sdgs.bappenas.go.id/tujuan-8/(10 Agustus 2021).

Komite Penanganan Covid-19 dan Pemulihan Ekonomi Nasional. (2021). Simak Aturan Lengkap PPKM Darurat! Berlaku 3 - 20 Juli, Jawa Bali. Jakarta: Komite Penanganan Covid-19 dan Pemulihan Ekonomi Nasional.

Murti, M. W. (9 Agustus 2021). PPKM Levels 4 and 3 Extended Again Until August 16. Tempo.co. Retrieved from https://en.tempo.co/read/1492739/ppkm-levels-4-and-3-extended-againuntil-august-16 (9 Agustus 2021).

Paramaditha, A. (6 Juli 2021). PPKM Darurat Necessary for Sustainable Recovery in Indonesia. The Jakarta Post. Retrieved from https://www.thejakartapost.com/news/2021/07/06/ppkmdarurat-necessary-for-sustainable-recovery-in-indonesia.html (9 Agustus 2021).

Sasongko, Y. A. T. (25 Januari 2021). Catatan Apik di Tengah Pandemi, Pendapatan GoFood Naik 20 Kali Lipat. Kompas.com. Retrieved from https://money.kompas.com/read/2021/01/25/191200726/catatan-apik-di-tengah-pandemipendapatan-gofood-naik-20-kali-lipat (10 Agustus 2021).

Satuan Tugas Penangan Covid-19. (8 Agustus 2021). Data Sebaran. Covid19.go.id. Retrieved from https://covid19.go.id/ (8 Agustus 2021).

Setyowati, D. (22 Januari 2021). Gojek: Pendapatan GoFood Tumbuh 20 Kali, Terbanyak Dipesan Ayam Goreng. Katadata. Retrieved from https://katadata.co.id/desysetyowati/digital/600aea21ae0f0/gojek-pendapatan-gofoodtumbuh-20-kali-terbanyak-dipesan-ayam-goreng (10 Agustus 2021).

Thomas, V. F. (6 Juli 2021). Govt Expects Indonesia to Miss 2021 GDP Growth Target. The Jakarta Post. Retrieved from https://www.thejakartapost.com/news/2021/07/06/govtexpects-indonesia-to-miss-2021-gdp-growth-target.html (10 Agustus 2021).

Ulya, F. N. and Sukmana, Y. (10 Agustus 2021). PPKM diperpanjang Lagi, Pertumbuhan Ekonomi Bisa Kembali Anjlok. Kompas.com. Retrieved from https://money.kompas.com/read/2021/08/10/125256726/ppkm-diperpanjang-lagipertumbuhan-ekonomi-bisa-kembali-anjlok?page=all (10 Agustus 2021).

World Health Organization. (2021). Covid-19 Dashboard. Retrieved from https://covid19.who.int/table (8 Agustus 2021) 